Journal of Engineering Sciences, Assiut University, Vol. 36, No. 4, pp.951 -961, July 2008

\title{
COMPUTATIONAL PREDICTION OF WATER-FLOW CHARACTERISTICS IN SPIRAL SEPARATORS: PART II, THE PRIMARY AND SECONDARY FLOWS
}

\author{
Doheim, M. A*., Abdel Gawad, A. F. ${ }^{* *}$, Mahran, G. M. A. ${ }^{* *}$, \\ Abu-Ali, M. H.*, and Rizk, A. M.* \\ * Mining and Metallurgical Eng. Dept., Faculty of Engineering, Assiut Univ. \\ ** Mechanical Power Eng. Dept., Faculty of Engineering, Zagazig University. \\ *** Mining and Petroleum Eng. Dept. Faculty of Engineering, Al-Azhar Univ.
}

(Received April 17, 2008 Accepted June 9, 2008)

\begin{abstract}
This study presents a mathematical model to predict water-flow characteristics, especially primary (downstream) and secondary velocities on the spiral trough. The study is based on volume of Fluid (VOF) approach and turbulence modeling. The applied turbulence models are $k$ $\varepsilon, R N G k-\varepsilon, S S T k-\omega$, and RSM. The results show that the primary velocity increases on the spiral trough with increasing of the radial distance from central column, and the air friction with the water decreases the primary velocity at the free surface. The model is validated against experimental data from LD9 coal spiral. Comparisons between the predicted and the measured values show good agreements, and the RSM is the most accurate turbulence model while the SST $k$ - $\omega$ model is the lowest accuracy.
\end{abstract}

KEYWORDS: Spiral separator, Free-surface flow, Computational simulation, Turbulence modeling, Primary flow, Secondary flow.

\section{INTRODUCTION}

Spiral separators are one of the most simple and efficient methods for both mineral processing and coal preparation. They sort particles according to the differences in specific gravity, size and shape [1-4]. In recent years, spiral separators are widely used due to their low cost and negligible environmental impact [5].

Until the late 1980s, most of publications concerning the modeling of spirals demonstrated empirical models [4]. Holland-Batt [6,7] presented an empirical model to predict primary and secondary velocities according to Manning's equation. Burch [8] started a fluid flow mechanistic model or $C F D$ model, which is based on fluid mechanics. He assumed the pulp to be a liquid of uniform viscosity and that the secondary flow would not affect the primary flow. Wang and Andrews [4], Jancar et al. $[9,10]$, and Matthews et al. $[11,12]$ contributed in the development of CFD modeling for spiral concentrators.

The present study introduces a numerical model for the prediction of primary and secondary velocities. The model is based on VOF scheme $[13,14]$. The effect of the force of surface tension between water and air is taken into account. Because of the turbulent nature of the flow in the spiral trough, four turbulence models, namely: $k-\varepsilon$, $R N G k-\varepsilon, S S T k-\omega$, and $R S M$ models are employed. One of the objectives is to find out 
the most appropriate turbulence model for the present problem. The present model is validated using the experimental data of others $[15,16]$.

\section{GEOMETRY OF SPIRAL SEPARATOR AND FLOW BEHAVIOUR}

Details are given and discussed in part I.

\section{GOVERNING EQUATIONS AND COMPUTATIONAL ASPECTS}

Details are given and discussed in part I.

\section{RESULTS AND DISCUSSIONS}

In the present work, the predicted results are compared with the experimental studies of others $[15,16]$. The study focuses on primary and secondary velocities of the water flow.

\subsection{Primary Velocity}

Figure 1 shows the present predictions and the experimental findings of others for the profiles of the primary velocity at the free-surface across the trough of the spiral separator. Generally, there is a good agreement between the measured and the predicted values, especially in the inner region of spiral trough. Figure 2 shows the experimental and predicted primary velocity profiles across the trough at a depth of 1 $\mathrm{mm}$. There is a good agreement between the measured and the predicted values, especially for $R S M$ results. Figures 3 and 4 show the measured and predicted primary velocity profiles at depths of 3 and $5 \mathrm{~mm}$ for three different flow rates. Figure 3 shows the measured and the predicted primary velocity profiles at depth of $3 \mathrm{~mm}$ for three different flow rates. Again, there is a good agreement between predicted and measured values of primary velocity.

Figure 4 shows the measured and the predicted primary velocity profiles at depth of $5 \mathrm{~mm}$ for three different flow rates. There are poor agreement between the predicted and the experimental values as shown in Figure $4 \mathrm{a} \& \mathrm{~b}$ while Figure $4 \mathrm{c}$ shows good agreement. Generally, as shown in the Figures 1 to 4, the agreement becomes poorer as the flow depth increases and the agreement becomes better as the flow rate increases. Figure 5 shows the contours of the primary velocity at flow rate $4 \mathrm{~m}^{3} / \mathrm{hr}$. The present predictions of the four turbulence models are shown in Fig. 5. The predictions of the $R N G k-\varepsilon$ and $R S M$ models for the contours of the primary velocity are shown in Fig. 6. Two flow rates of 6 and $8 \mathrm{~m}^{3} / \mathrm{hr}$ are considered in Fig. 6 .

In general, the primary velocity across the trough increases smoothly with radial distance from central column. The increase of the flow rate has a negligible effect on the flow velocity in the inner region. However, the flow rate affects clearly the flow velocity in the outer region. Table 1 shows the maximum values of primary velocity in the outer region of the trough. 
Table (1) Maximum values of primary velocity in outer region of the trough.

\begin{tabular}{|l||c||c|c|}
\hline Water flow rate $\left(Q_{\text {water }}\right)\left(\mathrm{m}^{3} / \mathrm{hr}\right)$ & 4 & 6 & 8 \\
\hline \hline Numerical predictions $(\mathrm{m} / \mathrm{s})$ & 1.9 & 2.3 & 2.4 \\
\hline \hline Experimental results $[15,16](\mathrm{m} / \mathrm{s})$ & 1.8 & 1.9 & 2.1 \\
\hline
\end{tabular}

An error analysis was carried out using the sum-of-squares of the difference between predicted and measured values of primary velocity. Thus, it was found that the most accurate turbulence model is RSM. Whereas, SST $k$ - $\omega$ model has the lowest accuracy. Details of the error analysis are shown in Sec. 4.4.

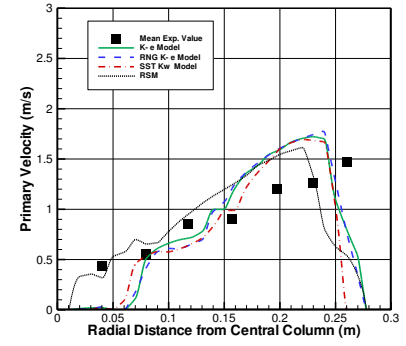

(a) Flow rate $4 \mathrm{~m}^{3} / \mathrm{hr}$.

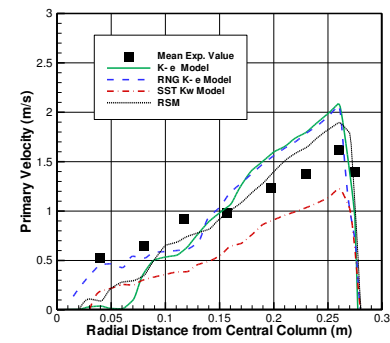

(b) Flow rate $6 \mathrm{~m}^{3} / \mathrm{hr}$.

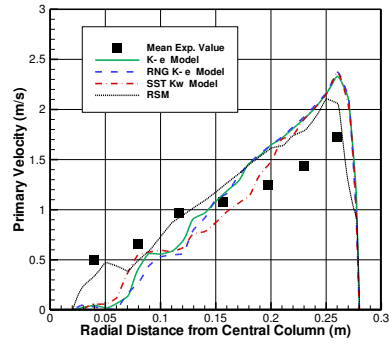

(c) Flow rate $8 \mathrm{~m}^{3} / \mathrm{hr}$.

Fig.1 Predicted and experimental [15] primary free-surface velocity.

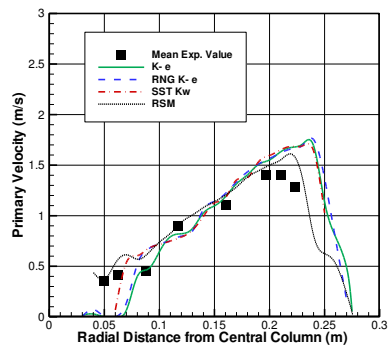

(a) Flow rate $4 \mathrm{~m}^{3} / \mathrm{hr}$.

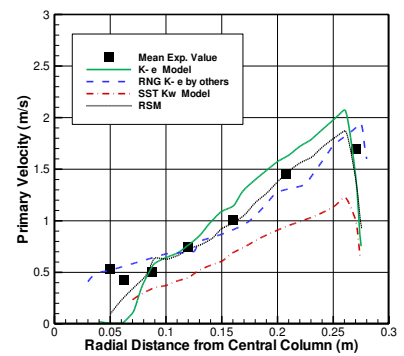

(b) Flow rate $6 \mathrm{~m}^{3} / \mathrm{hr}$.

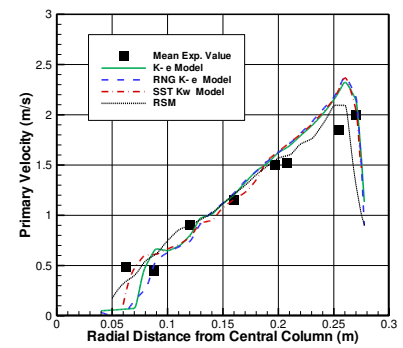

(c) Flow rate $8 \mathrm{~m}^{3} / \mathrm{hr}$.

Fig. 2 Predicted and experimental $[15,16]$ primary velocity at $1 \mathrm{~mm}$ flow-depth.

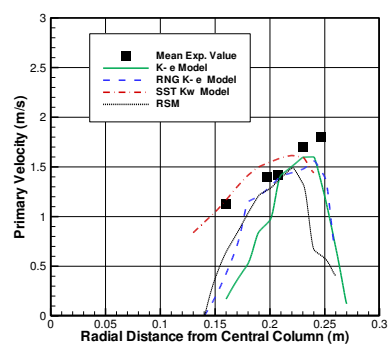

(a) Flow rate $4 \mathrm{~m}^{3} / \mathrm{hr}$.

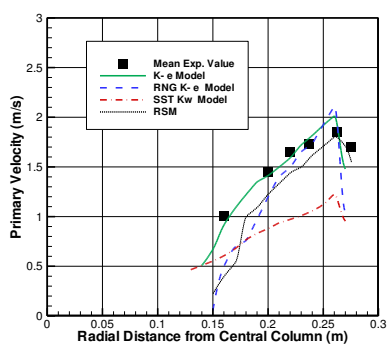

(b) Flow rate $6 \mathrm{~m}^{3} / \mathrm{hr}$.

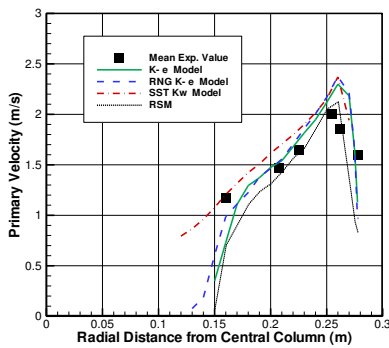

(c) Flow rate $8 \mathrm{~m}^{3} / \mathrm{hr}$.

Fig. 3 Predicted and experimental [15] primary velocity at $3 \mathrm{~mm}$ flow-depth. 


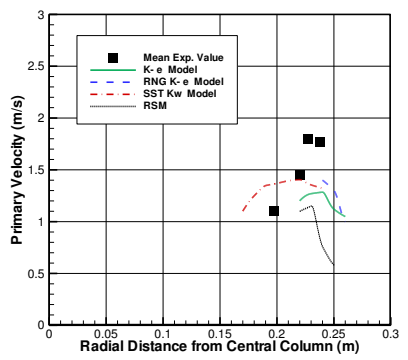

(a) Flow rate $4 \mathrm{~m}^{3} / \mathrm{hr}$.

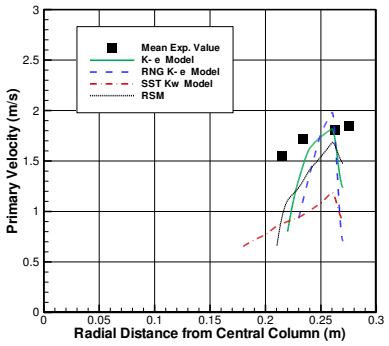

(b) Flow rate $6 \mathrm{~m}^{3} / \mathrm{hr}$.

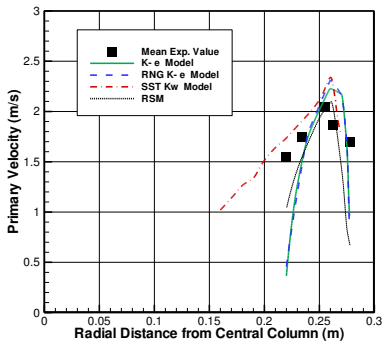

(c) Flow rate $8 \mathrm{~m}^{3} / \mathrm{hr}$. Fig. 4 Predicted and experimental [15] primary velocity at $5 \mathrm{~mm}$ flow-depth.

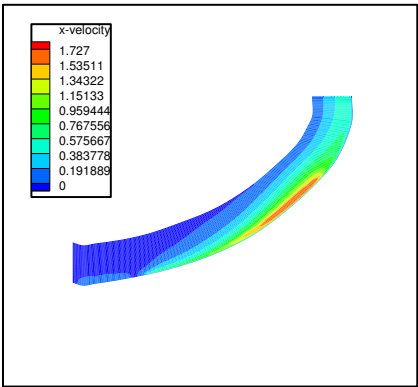

(a) $k-\varepsilon$ Model, $\mathrm{m} / \mathrm{s}$.

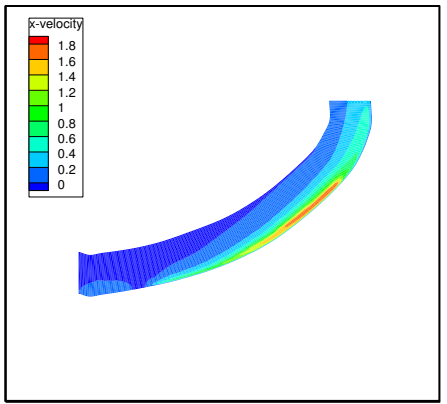

(c) RNG $k-\varepsilon$ Model, $\mathrm{m} / \mathrm{s}$.

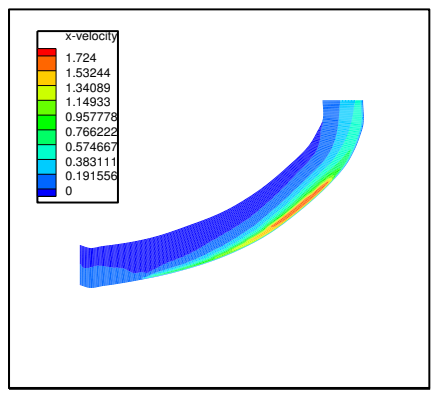

(b) SST $k-\omega$ Model, $m / s$.

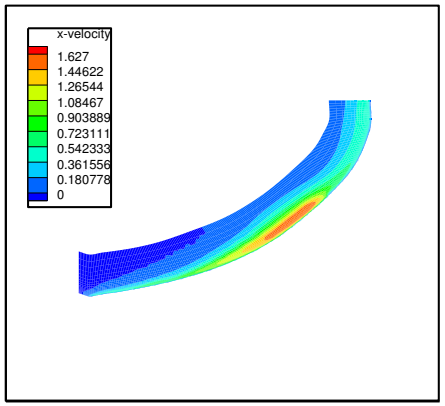

(d) RSM Model, $\mathrm{m} / \mathrm{s}$.

Fig. 5 Primary velocity contours $(\mathrm{m} / \mathrm{s})$ on spiral trough, flow rate $4 \mathrm{~m}^{3} / \mathrm{hr}$.

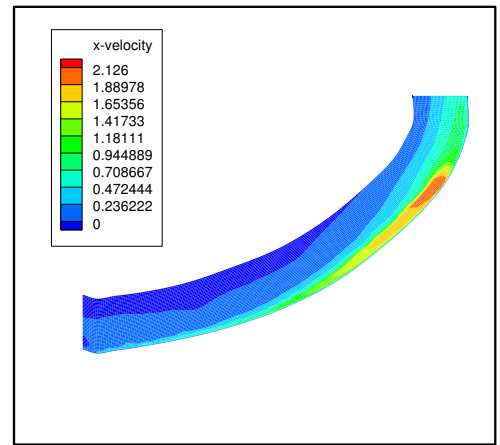

(a) $R N G k$ - $\varepsilon$ Model, flow rate $6 m^{3} / h r$.

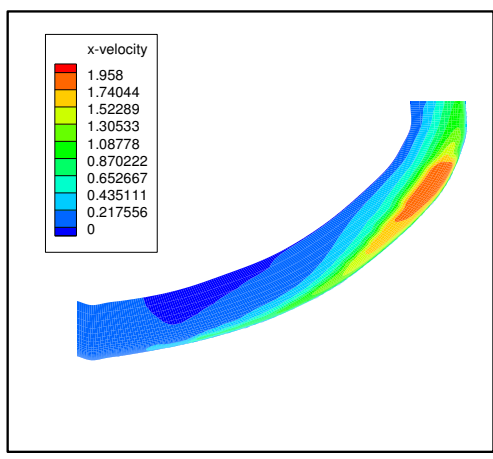

(b) $R S M$ Model, flow rate $6 \mathrm{~m}^{3} / \mathrm{hr}$. 


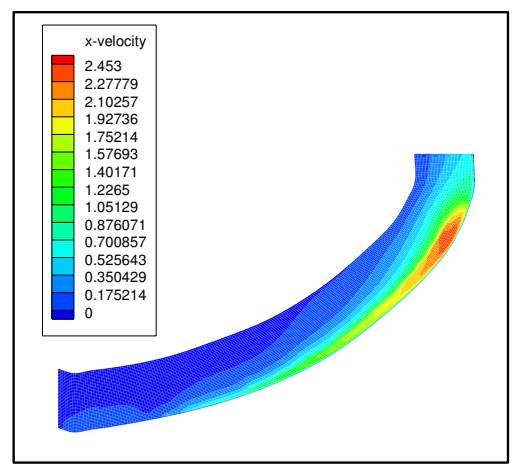

(c) $R N G k$ - $\varepsilon$ Model, flow rate $8 \mathrm{~m}^{3} / \mathrm{hr}$.

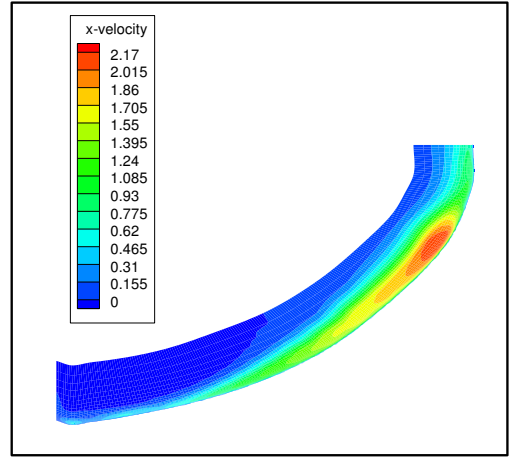

(d) RSM Model, flow rate $8 \mathrm{~m}^{3} / \mathrm{hr}$.

Fig. 6 Primary velocity contours $(\mathrm{m} / \mathrm{s})$ on spiral trough.

\subsection{Change of Primary Velocity with Water Height Fraction}

Figure 7 shows the variation of primary velocity with water height fraction at three different locations on the spiral trough. Water flow rate is $6 \mathrm{~m}^{3} / \mathrm{hr}$. These locations have radial distances of 5, 10, and $15 \mathrm{~cm}$ from the central column of the spiral. Water height fraction is measured from the bottom of the spiral trough to the surface of the water. Figure 7 illustrates that the primary velocity increases with the radial distance. Thus, the maximum velocities are found in the outer region of the spiral trough.

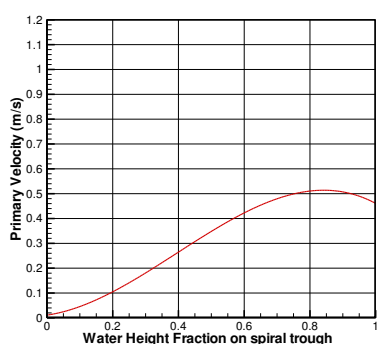

(a) $5 \mathrm{~cm}$ radial distance.

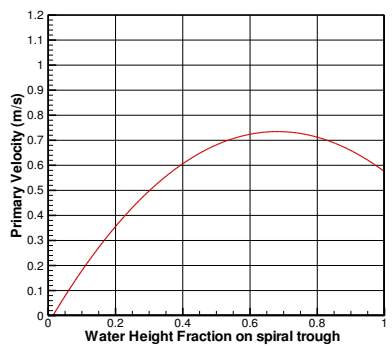

(b) $10 \mathrm{~cm}$ radial distance.

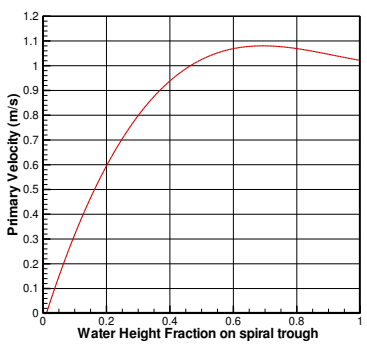

(c) $15 \mathrm{~cm}$ radial distance.

Fig. 7 Change of primary velocity with water height fraction, flow rate $6 \mathrm{~m}^{3} / \mathrm{hr}$.

Generally, the primary velocity increases with the height fraction. However, the maximum values of the primary velocity, at certain radial distance, are found below the free-surface. The air friction decreases the primary velocity at the free-surface.

\subsection{Secondary Velocity}

Figures 8-11 show the measured and the predicted results of the secondary velocity at free-surface as well as at depths of 1,3 , and $5 \mathrm{~mm}$, respectively. A positive velocity indicates flow outwards towards the outer edge of the spiral trough. Whereas, a negative value indicates flow inwards towards the central column of the spiral. The measured points are instantaneous values. The secondary velocity is very small compared to the primary velocity. The agreement in the outer zone between experimental and predicted values of secondary velocity is poor. Generally, at the higher flow rates $\left(6\right.$ and $8 \mathrm{~m}^{3} / \mathrm{hr}$ ), accumulations of very high secondary velocity points 
can be seen in the outer region of trough. Majority of values are negative, indicating a very strong inwards secondary flow in the outer region. In the outer region of the trough, high-rate turbulence is generated as a result of the steep velocity gradients. Thus, air entrainment is significant in this region. Figure 12 illustrates the secondary velocity contours at flow rate $4 \mathrm{~m}^{3} / \mathrm{hr}$. The present predictions of the four turbulence models are shown in Fig. 12. Figure 13 demonstrates the predictions of the contours of the secondary velocity for flow rates of 6 and $8 \mathrm{~m}^{3} / \mathrm{hr}$ using $R N G k-\varepsilon$ and $R S M$ models. Generally, the computational predictions tend to average the scattered instantaneous values of the secondary velocity in the outer region of the trough.

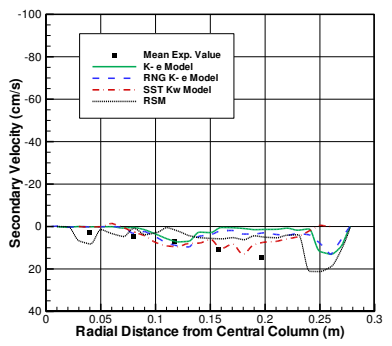

(a) Flow rate $4 m^{3} / h r$.

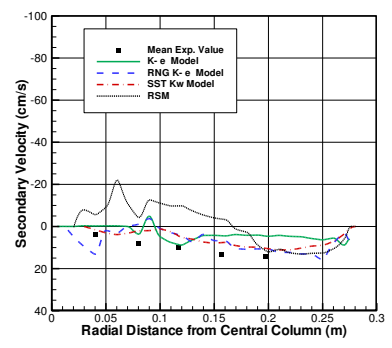

(b) Flow rate $6 \mathrm{~m}^{3} / \mathrm{hr}$.

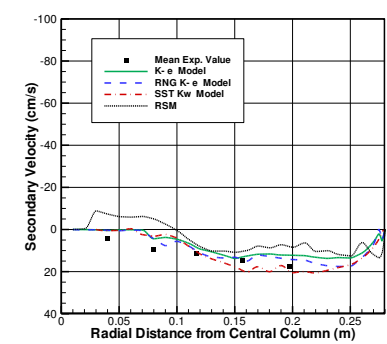

(c) Flow rate $8 m^{3} / h r$.

Fig. 8 Predicted and experimental [15] secondary free-surface velocity.

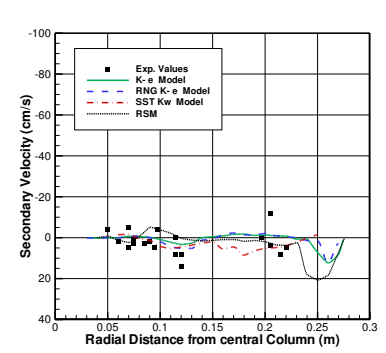

(a) Flow rate $4 \mathrm{~m}^{3} / \mathrm{hr}$.

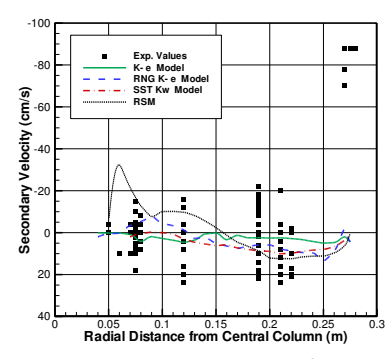

(b) Flow rate $6 \mathrm{~m}^{3} / \mathrm{hr}$.

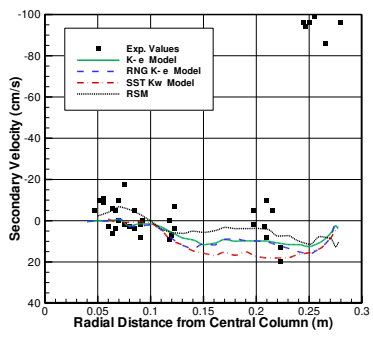

(c) Flow rate $8 \mathrm{~m}^{3} / \mathrm{hr}$.

Fig. 9 Predicted and experimental [15] secondary velocity at $1 \mathrm{~mm}$ flow-depth.

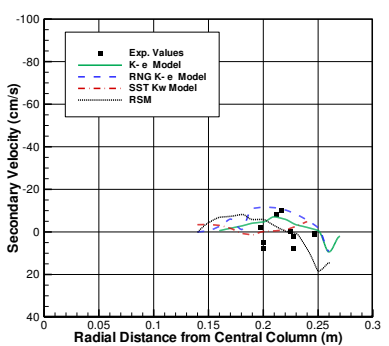

(a) Flow rate $4 \mathrm{~m}^{3} / \mathrm{hr}$.

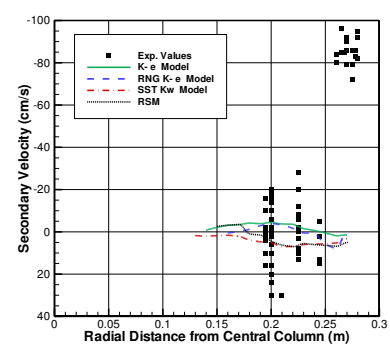

(b) Flow rate $6 \mathrm{~m}^{3} / \mathrm{hr}$.

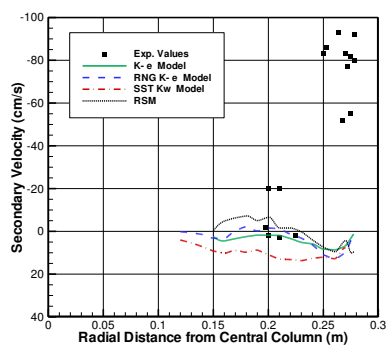

(c) Flow rate $8 m^{3} / h r$.

Fig. 10 Predicted and experimental [15] secondary velocity at $3 \mathrm{~mm}$ flow-depth. 


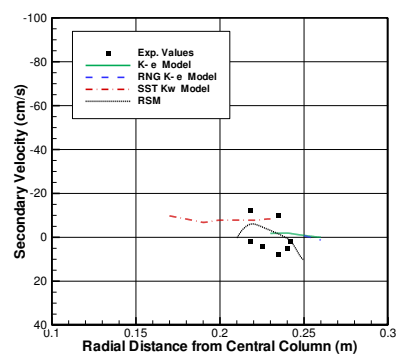

(a) Flow rate $4 \mathrm{~m}^{3} / \mathrm{hr}$.

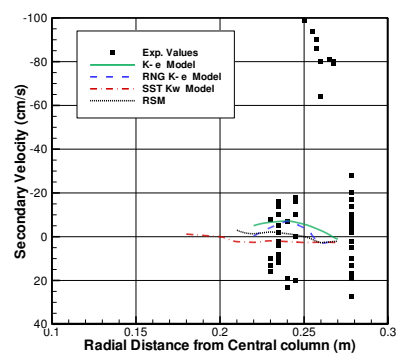

(b) Flow rate $6 \mathrm{~m}^{3} / \mathrm{hr}$.

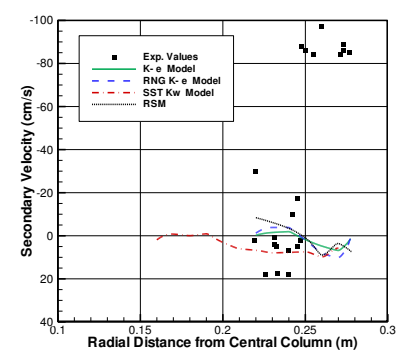

(c) Flow rate $8 \mathrm{~m}^{3} / \mathrm{hr}$.

Fig. 11 Predicted and experimental [15] secondary velocity at $5 \mathrm{~mm}$ flow-depth.

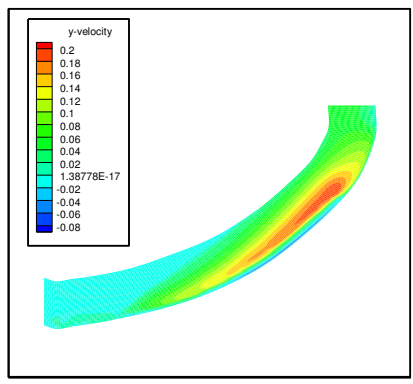

(a) $k$ - $\varepsilon$ Model, $\mathrm{cm} / \mathrm{s}$.

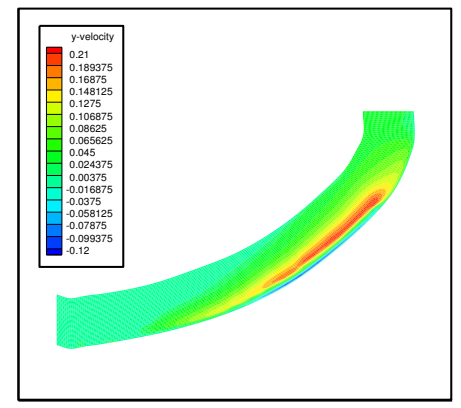

(c) $R N G k-\varepsilon$ Model, $\mathrm{cm} / \mathrm{s}$.

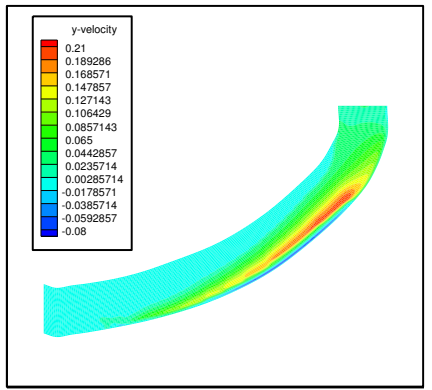

(b) SST k- $\omega$ Model, $\mathrm{cm} / \mathrm{s}$.

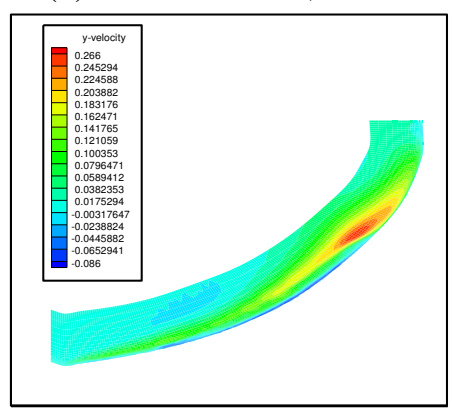

(d) RSM Model, $\mathrm{cm} / \mathrm{s}$.

Fig. 12 Secondary velocity contours $(\mathrm{m} / \mathrm{s})$ on spiral trough, flow rate $4 \mathrm{~m}^{3} / \mathrm{hr}$.

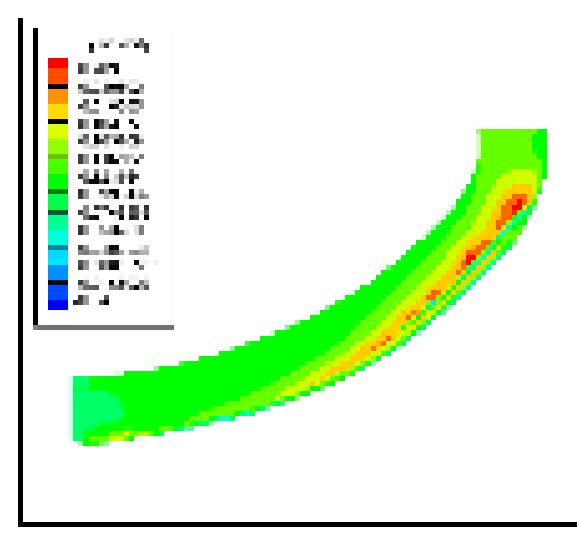

(a) $R N G k$ - $\varepsilon$ Model, flow rate $6 m^{3} / h r$.

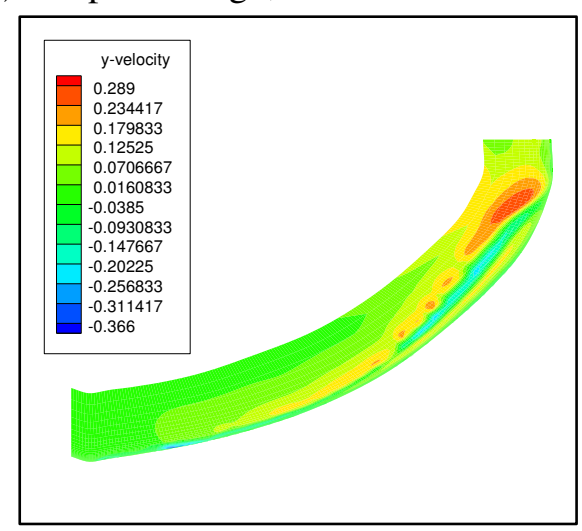

(b) $R S M$ Model, flow rate $6 \mathrm{~m}^{3} / \mathrm{hr}$. 


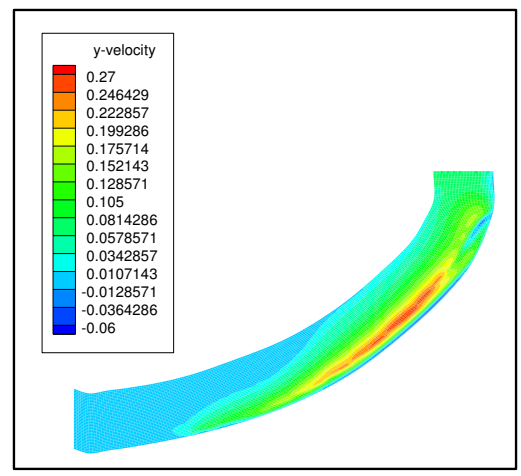

(c) $R N G k-\varepsilon$ Model, flow rate $8 \mathrm{~m}^{3} / \mathrm{hr}$.

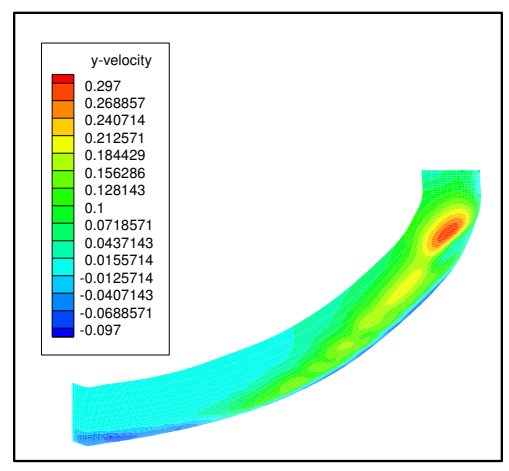

(d) $R S M$ Model, flow rate $8 \mathrm{~m}^{3} / \mathrm{hr}$.

Fig. 13 Secondary velocity contours $(\mathrm{m} / \mathrm{s})$ on spiral trough.

\subsection{Comparison between Turbulence Models}

To find the turbulence model that gives best predictions for the investigated problem, a comparison was carried out. The comparison is based on the error between the numerical predictions and the experimental values. The experimental results of Holtham [15] were taken as the reference values. To account for both positive and negative errors, the square of the error is considered. Table 2 shows comparison between different turbulence models. The Table covers also the numerical results of others. Each of the values that appear in Table 2 represents the summation of the squared-errors at all points of measurements along the radial distance from the central column of the spiral trough.

It is noticed that $R S M$ predictions are the closest to the experimental results. Thus, $R S M$ is the best model for computing the flow of spiral separators. It is also obvious that the present predictions of $k-\varepsilon$ and $R N G k-\varepsilon$ are better than their corresponding predictions of Matthews et al. [11,12]. Thus, it seems that the present computational scheme gives comparatively good results. It is highly recommended to use $R S M$ in such type of problems although it needs the greatest computational effort and CPU run-time among all turbulence models as shown in part I.

Table (2) Error comparison for different turbulence models.

\begin{tabular}{|c|c|c|c|c|c|c|c|}
\hline No. & Quantity & $k-\varepsilon$ & $\begin{array}{c}\text { k- } \varepsilon \\
\text { Matthews et } \\
\text { al. }[11,12]\end{array}$ & $\begin{array}{c}R N G \\
k-\varepsilon\end{array}$ & $\begin{array}{c}\text { RNG k- } \varepsilon \\
\text { Matthews et } \\
\text { al. }[11,12]\end{array}$ & $\begin{array}{l}S S T \\
k-\omega\end{array}$ & $R S M$ \\
\hline 1 & $\begin{array}{c}\text { Primary velocity } \\
\text { Free-surface } \\
\left(4 \mathrm{~m}^{3} / \mathrm{hr}\right)\end{array}$ & 3.366 & 6.041 & 3.246 & 6.0916 & 1.952 & 1.948 \\
\hline 2 & $\begin{array}{c}\text { Primary velocity } \\
1 \mathrm{~mm} \text {-depth } \\
\left(4 \mathrm{~m}^{3} / \mathrm{hr}\right)\end{array}$ & 8.652 & 12.641 & 9.188 & 12.938 & 7.284 & 3.606 \\
\hline 3 & $\begin{array}{l}\text { Primary velocity } \\
3 \mathrm{~mm} \text {-depth } \\
\left(4 \mathrm{~m}^{3} / \mathrm{hr}\right)\end{array}$ & 4.614 & 14.680 & 3.433 & 13.067 & 2.892 & 2.448 \\
\hline
\end{tabular}




\begin{tabular}{|c|c|c|c|c|c|c|c|}
\hline 4 & $\begin{array}{c}\text { Primary velocity } \\
5 \mathrm{~mm} \text {-depth } \\
\left(4 \mathrm{~m}^{3} / \mathrm{hr}\right)\end{array}$ & 5.092 & 15.922 & 7.224 & 18.956 & 6.640 & 4.173 \\
\hline 5 & $\begin{array}{c}\text { Primary velocity } \\
\text { Free-surface } \\
\left(6 \mathrm{~m}^{3} / \mathrm{hr}\right)\end{array}$ & 3.217 & 3.660 & 2.400 & 3.461 & 4.413 & 1.515 \\
\hline 6 & $\begin{array}{c}\text { Primary velocity } \\
1 \mathrm{~mm} \text {-depth } \\
\left(6 \mathrm{~m}^{3} / \mathrm{hr}\right)\end{array}$ & 1.908 & 31.494 & 1.455 & 31.532 & 4.391 & 1.373 \\
\hline 7 & $\begin{array}{c}\text { Primary velocity } \\
3 \mathrm{~mm} \text {-depth } \\
\left(6 \mathrm{~m}^{3} / \mathrm{hr}\right)\end{array}$ & 3.748 & 38.301 & 4.396 & 32.548 & 8.078 & 1.094 \\
\hline 8 & $\begin{array}{c}\text { Primary velocity } \\
5 \mathrm{~mm} \text {-depth } \\
\left(6 \mathrm{~m}^{3} / \mathrm{hr}\right)\end{array}$ & 6.965 & 30.240 & 10.370 & 25.123 & 8.710 & 4.923 \\
\hline 9 & $\begin{array}{c}\text { Primary velocity } \\
\text { Free-surface } \\
\left(8 \mathrm{~m}^{3} / \mathrm{hr}\right)\end{array}$ & 11.244 & 14.347 & 10.911 & 13.946 & 9.785 & 4.799 \\
\hline 10 & $\begin{array}{c}\text { Primary velocity } \\
1 \mathrm{~mm} \text {-depth } \\
\left(8 \mathrm{~m}^{3} / \mathrm{hr}\right)\end{array}$ & 4.437 & 9.948 & 3.853 & 14.822 & 2.812 & 2.664 \\
\hline 11 & $\begin{array}{c}\text { Primary velocity } \\
3 \mathrm{~mm} \text {-depth } \\
\left(8 \mathrm{~m}^{3} / \mathrm{hr}\right)\end{array}$ & 0.880 & 9.348 & 1.113 & 7.1759 & 6.788 & 0.840 \\
\hline 12 & $\begin{array}{c}\text { Primary velocity } \\
5 \mathrm{~mm} \text {-depth } \\
\left(8 \mathrm{~m}^{3} / \mathrm{hr}\right)\end{array}$ & 2.433 & 6.735 & 2.457 & 6.758 & 16.867 & 2.425 \\
\hline
\end{tabular}

\section{CONCLUSIONS}

1- The present numerical model has employed four turbulence models, namely: $k$ $\varepsilon, R N G k-\varepsilon, R S M$, and SST $k-\omega . R S M$ is the most accurate turbulence model according to comparisons between the predicted and the measured values.

2- The suggested numerical model can predict water velocities on the trough for any spiral separator after modifying the geometry to the required separator.

3- The primary velocity across the spiral trough increases smoothly with the radial distance from the central column. The primary velocity varies negligibly with the flow rate in the inner region of the spiral trough. An obvious effect of the flow rate on the primary velocity is seen in the outer region of the trough. There is a good agreement between the present numerical predictions and the measured values of others.

4- The secondary velocity is very small compared to the primary velocity. It is difficult to accurately predict the secondary velocity in the outer region of the spiral trough. This may be attributed to the high-unsteady nature of the secondary flow in the outer region.

The present study is a step towards modeling of the particulate flow on spiral separators. 


\section{REFERENCES}

[1] Davies, P. O. J., Goodman, R. H., and Deschamps, J. A., "Recent Development in Spiral Design, Construction and Application," J. Minerals Engineering, Vol. 4, No. 3-4, pp. 437-456, 1991.

[2] Holtham, P. N., "Primary and Secondary Fluid Velocities on Spiral Separators," J. Minerals Engineering, Vol. 5, No.1, pp. 79-91, 1992.

[3] Glass, H. J., Minekus, N. J., and Dalmijn, W. L., "Mechanics of Coal Spirals," J. Minerals Engineering, Vol. 12, No. 3, pp. 271-280, 1999.

[4] Wang, J. W., and Andrews, J. R. G., "Numerical Simulations of Liquid Flow on Spiral Concentrators," J. Minerals Engineering, Vol. 7, No. 11, pp. 1363-1385, 1994.

[5] Kapur, P. C., and Meloy, T. P., "Spiral Observed," International Journal of Mineral Processing, Vol. 53, pp. 15-28,1998.

[6] Holland-Batt, A. B., "Spiral Separation: Theory and Simulation," Trans. Inst. Min. Metall. (Sec. C), Vol. 98 (January-April), pp. C46-C59, 1989.

[7] Holland-Batt, A. B., and Holtham, P. N., "Particle and Fluid Motion on Spiral Separators," J. Minerals Engineering, Vol. 4, No. 3-4, pp. 457-482, 1991.

[8] Burch, C. R., "Helicoid Performance and Fine Cassiterite-Contributed Remarks," Trans. Inst. Min. Metall., Vol. 71, pp. 406-415, 1962.

[9] Jancar, M. L., Holtham, P. N., Davis, J. J., and Fletcher, C. A. J., "Approaches to the Development of Coal Spiral Models," An International symposium, Soc. Mining, Metal and Exploration, Littliton, USA, pp. 335-345, 1995.

[10] Jancar, T., Fletcher, C. A. J., Holtham, P. N., and Reizes, J. A., "Computational and Experimental Investigation of Spiral Separator Hydrodynamics," Proc. XIX Int. Mineral Processing Congress, San Francisco, USA, 1995.

[11] Matthews, B. W., Fletcher, C. A. J., and Partridge, A. C., "Computational Simulation of Fluid and Dilute Particulate Flows on Spiral Concentrators," Applied Mathematical Modelling, Vol. 22, pp. 965-979, 1998.

[12] Matthews, B. W., Fletcher, C. A. J., Partridge, A. C., and Vasquez, S., "Computations of Curved Free Surface Water Flow on Spiral Concentrators," J. Hydraulic Engineering, Vol. 125, No. 11, pp. 1126-1139, 1999.

[13] Hirt, C. W., and Nichols, B. D., "Volume of Fluid (VOF) Method for the Dynamics of Free Boundaries, J. Computational Physics, Vol. 39, pp. 201-225, 1981.

[14] Harvie, D., and Fletcher, D., "The Stream Volume of Fluid Advection Algorithm," The ANZIAM Journal, Vol. 42 (E), pp. C690-C711, 2000.

[15] Holtham, P. N.,"Vol.1 Experimental Validation of a Fundamental Model of Coal Spirals" Australian Coal Association research program (ACARP), 1997.

[16] Golab, K. J., and Holtham, P. N.,"Validation of a Computer model of fluid flow on the spiral separator" Innovation in Physical Separation Technologies, Mozely Memorial Symp., Inst. Min. Metall., London,1997. 


\section{التوقع الحسابى لخصاص سريان الماء فى الفاصل الحلزونى}

\section{الجزء الثانى: السرعات الأساسية والثانوية}

هذة الدراسة تقام نموذج رياضى مقترح لحساب خصائص سريان الماء و بخاصة السرعات الأساسية

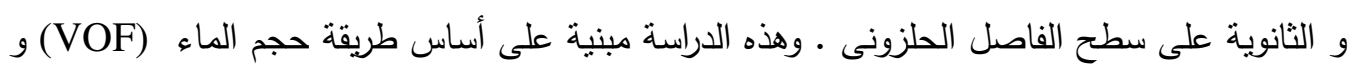

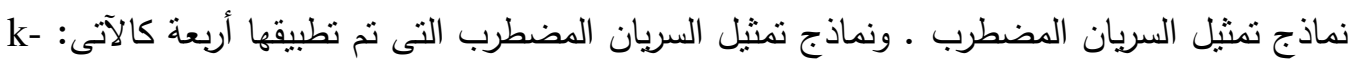

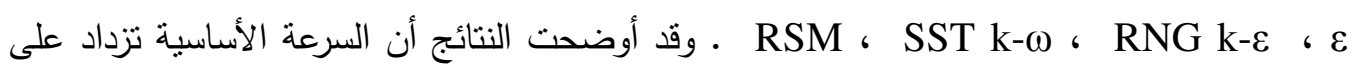

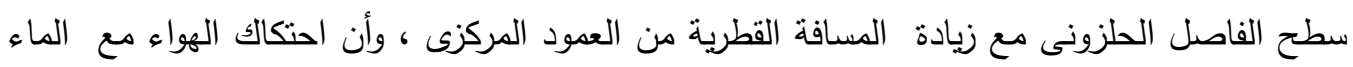

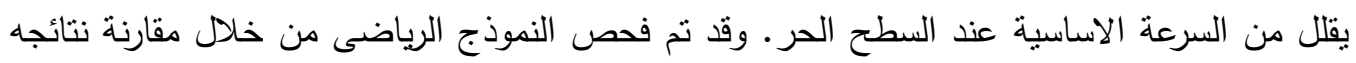

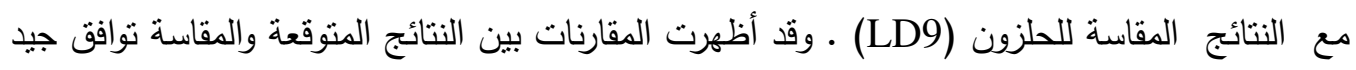

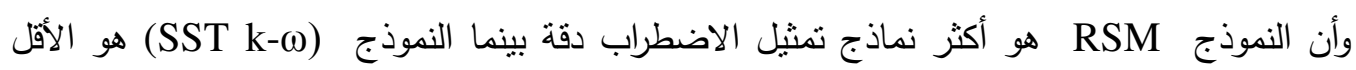

